\title{
Identity Crisis suffered by the Women Protagonists in the Novels of Arundhati Roy and Kiran Desai: A Comparative Study
}

\author{
Rajneesh Kumar \\ Ph.D. Research Scholar, DAV University, Jalandhar/ Sr. Asst. Professor and Head, Deptt.of \\ English, Govt. Arts E Sports College, Jalandhar, Punjab, India. ORCID ID: oooo-0oo2-5850- \\ 7467. Email: prof.rajneesh@yahoo.co.in
}

\begin{abstract}
Identity crisis is one of the most dominating thematic concerns in the novels of Arundhati Roy and Kiran Desai. Sucked into the vortex of ascribed and achieved identities, the characters portrayed by these two authors struggle to create their personal identity and individuality. Roy has dwelt on the idea of identity on several platforms, be it on the page or stage. She has an in-depth understanding of individual and collective identities. On the other hand, Desai focuses on multiculturalism and dislocation in families that pose athreat to one's social, civic and cultural identity. Her works offer some fresh insights into diaspora identity. This paper critically examines identity crisis suffered by the women protagonists in the novels of Roy andDesai within the comparative literature study framework by focusing on the method of thematology. Roy mulls over the significance of women in families and society. There is no dispute regarding their inevitable role, but their status is definitely a matter of debate. In her debut novel, Roy speaks freely about the concerns of women, but the issue of identity crisis outdoes in her second novel due to the polyphonic sounds of her women characters. Desai, to the contrary, presents an idealistic picture of Indian women. This paper delineates that Roy and Desai unearths various dimensions of womanhood in general and wifehood in particular. Both Roy and Desai deal with the issue of identity against the socio-cultural backdrop of India. They depict a panoramic view of identity crisis faced by women.
\end{abstract}

Keywords: Arundhati Roy, Kiran Desai, Identity crisis, Woman, Wife, Theme.

\section{Introduction}

The idea of identity has been explored from the viewpoints of psychology, philosophy, history, political science, sociology, science, geography and economics. Erik H. Erikson, a prominent psychologist, coined the term 'identity crisis' in Childhood and Society in 1950. He presents eight stages of psychosocial development whichcreate, change or lose the identity of an individual. Basic Trust vs. Basic Mistrust, Autonomy vs. Shame and Doubt, Initiative vs. Guilt, Industry vs. Inferiority, Identity vs. Role Confusion, Intimacy vs. Isolation, Generativity vs. Stagnation and Ego Integrity vs. Despair are the 'Eight Ages of Man' mentioned in Erikson's book. James Marcia elaborates on four types of identity statuses, known as Marcian theory of identity. The first type is identity foreclosure, a situation where a commitment is made without exploring alternatives. Here, ideas are accepted without questioning. Identity diffusion is the second status, which leads to social isolation. It is a self-destructive identity role without any commitment. The third type is identity moratorium, which suggests the active exploration of alternatives. It throws light on

(C) AesthetixMS 2020. This Open Access article is published under a Creative Commons Attribution Non-Commercial 4.0 International License (http://creativecommons.org/licenses/by-nc/4.0/), which permits non-commercial re-use, distribution, and reproduction in any medium, provided the original work is properly cited. For citation use the DOI. For commercial re-use, please contact editor@rupkatha.com. 
open-mindedness and thoughtfulness of an individual. One is ready to explore choices but there is no final commitment. The fourth status is identity achievement, which is a suitable resolution to multiple identity crises. It shows an individual's firm commitment. This paper studies the theme of identity in the novels under study in the light of the psychosocial approaches of Erikson and Marcia.

Most women writers inevitably lean towards female characters when speak about the issue of identity crisis. Roy and Desai have also portrayed their women characters in a highly noteworthy manner. Roy has depicted significant women characters, such as Ammu, Rahel, Baby Kochamma, Mammachi and Kalyani in The God of Small Things (1997) and Tilottama, Maryam Ipe, Jahanara Begum, Zainab, LoveleenKaur, Sangeeta Madam and Revathy in The Ministry of Utmost Happiness (2017) who suffer from the malady of identity crisis. On the other hand, Desai's women characters, such as Kulfi and Pinky in Hullabaloo in the Guava Orchard (1998) and Bela, Sai, Noni and Lola in The Inheritance of Loss (2006) are quite substantial in search of identity. Both Roy and Desai have dealt with the theme of identity by keeping the Indian environment in mind. They valiantly elaborate on the multiple issues related to identity crisis suffered by women.

\section{Identity Crisis suffered by Women Protagonists:}

The patriarchal society of India snubs women's quest for independence with an iron fist. Roy elucidates her viewpoint with a trio in her first novel. Mammachi, her daughter Ammu and her granddaughter Rahel suffer at the hands of men in general and husbands in particular. The trio undergoes physical and psychological torments as an inevitable part of their lives. The marriage of Ammu and Rahel ends in divorce, whereas Mammachi gets an unusual separation from her husband. Pappachi stops beating Mammachi when his son Chacko forbids him to do so, but the former never speaks to his wife after that incident:

Mother of Ammu and Chacko, Mammachi is also a physically and psychologically abused wife alike so many women in different societies who undergo torture and trauma and never speak out. (Al-Quaderi, 2011, p. 66)

Roy's novel sheds light how familial and homely duties act as hurdles in women's lives in India. She gives references from Hindu mythology to validate her point. In the Mahabharata, the Pandavas put their wife, Draupadi, at stake in the game of dice. Yudhishthira completely changes Draupadi's identity by imposing his own sense of proprietary over her. Roy gives a thoughtprovoking turn to this pathetic incident: "Draupadi (strangely angry only with the men that won her, not the ones that staked her)" (Godp. 234). The novelist propagates that the life of almost all Indian wives is no better than that of Draupadi in a way or the other. There are a few who resist likeAmmu, but the rest of them suffer silently like Mammachi.

Roy deliberateson the importance of women in a family and society. There is no disagreement regarding their vital role, but their status is unquestionably a matter of discussion:

In the works of Arundhati Roy, the women characters are illustrated not only as women but also as human beings multipart and baffled. (Hariharansudan, 2017, p. 160)

Roy discusses the physical and psychological pressures on wives through not only major female characters but also the minor characters like Kalyani, wife of K. N. M. Pillai, highlighting the widespread atrocities against women in the Indian society. The novelist introduces Kalyani as a beautiful woman with attractive physical features. Kalyani's status as a spouse is not of equality:

She referred to her husband as addehamwhich was the respectful form of 'he', whereas 'he' called her 'edi' which was, approximately, 'Hey, you!'” (Roy, God, 1997, p. 270) 
Chacko visits Comrade Pillai's home and Kalyani asks him to wait as her husband is expected to return any moment. Kalyani engages her niece, Latha, to recite a poem for the guest. In the meantime, the master of the house, Comrade Pillai, arrives. The novelist exhibits the power of the man over all the women in the house:

He had the easy authority of the Man of the House. He smiled and nodded a greeting to Chacko, but did not acknowledge the presence of his wife or his mother. Latha's eyes flicked towards him for permission to continue with the poem. It was granted. (p. 272)

Comrade Pillai's subsequent gesture signals the supremacy of husbands as well as the degradation of wives:

Comrade Pillai took off his shirt, rolled it into a ball and wiped his armpits with it. When he finished, Kalyani took it from him and held it as though it was a gift. A bouquet of flowers. (p. 272)

Roy reveals how gender roles are fixed and rigid in the traditional social setup of India. The novelist shares some more episodes where the wives continue to suffer silently and meekly.

Roy discusses the issue of identity crisis in her second novel, The Ministry of Utmost Happiness, in detail due to the polyphonic sounds of her women characters. Tilo, her mother Maryam Ipe, Jahanara Begum and Revathy remain significant throughout the novel. The Indian society blindly follows the patriarchal system where the mothers are worshipped, but at the same time, they suffer the most:

The suppression of women starts in their own house and is a consequence of a family and social mechanism that has evolved over centuries in traditional Indian society. (Neelima, 2016, p. 38)

The three mothers in the novel, namely Jahanara, Maryam and Revathy undergo physical and mental hardships due to their daughters. They put their own identities at stake to affirm their respective daughters' personal and social identities. Jahanara gives birth to a hermaphrodite, namely Anjum; Maryam's daughter, Tilo, is born out of wedlock; Revathy's daughter, Miss UdayaJebeen, is the outcome of a brutal rape by six policemen. The mothers are benevolent, whereas the orthodox society is malevolent towards them. Jahanara suffers trauma, so does her daughter, Anjum. Maryam disowns her illegitimate daughter, Tilo, and bears physical distress in her early life and mental anguish in the later part of her life. Tilo also faces the hardships of life throughout the novel. Finally, Revathy tolerates the brutal rape and her daughter, Miss UdayaJebeen, suffers identity crisis in her infancy. Roy presents her women characters as the victims of the Indian patriarchal society.

Bela, alias Nimi Patel, suffers not only as a daughter of a rich businessman but also as a wife of a powerful judge. Desai's second novel, The Inheritance of Loss, makes a sharp comment upon the tragic plight of Indian wives through a submissive woman, namely Bela. Like her counterpart Roy, Desai also exemplifies that Indian women do not possess a home of their own. Without seeking Bela's consent, her father fixes her marriage with Jemu, an aspiring judge. The daughter has no option except to give her approval:

If Jemu succeeded in his endeavor, she would be the wife of one of the most powerful men in India. (Desai, Inheritance, 2006, p. 91)

In the beginning, Jemu is captivated by the beauty of his underage wife who is just fourteen years old at the time of their marriage. Desai pictures a realistic scene of their wedding night where the 
young girl is terrified, but she is expected to act in accordance with the rotten tradition of child marriage. The first attack on a girl's self-identity happens to be the process of renaming her:

When she married, her name was changed into the one chosen by Jemubhai's family, and in a few hours, Bela became Nimi Patel. (p. 91)

Bela's long cherished self-identity comes to an end with a new name. Rupali M. Gaikwad sheds light on the crisis of self-identity through various women characters of some select women novelists. She says:

Self-Identity as a term is defined by the experts as the recognition of one's potential \& qualities as an individual, especially in relation to the social context. (Gaikwad, 2017, p. 177)

Bela is the "most beautiful daughter" (Desai, Inheritance, 2006, p. 90-91) of Bomanbhai but being a girl, her luck is hard. Desai describes Bela's beauty through the eyes of the cook when Sai forces him to tell her about her grandmother:

You could tell from her features, which were delicate; her toes, nose, ears, and fingers were all very fine and small, and she was very fair-just like milk. Complexion-wise, they said, you could have mistaken her for a foreigner. Her family only married among fifteen families, but an exception was made for your grandfather because he was in the ICS. (p. $88)$.

Leaving his beautiful young wife behind, Jemu goes to chase his dream in England. As far as Bela is concerned, she leads an indolent life as a daughter and wife.

Jemu returns from England as a judge, who is completely fascinated with the English lifestyle and has no concern for his Indian wife. With the double authority, i.e. as a husband and judge, he does not leave any scope for the assertion of her identity. Nimi continues to lead an idle and useless life throughout the novel:

Nimi was left to sit alone in Bonda; three weeks out of four, she paced the house, the garden. She had spent nineteen years within the confines of her father's compound and she was still unable to contemplate the idea of walking through the gate. (p. 171)

The judge starts teaching her the British lifestyle, but he does not succeed. Jemu, a male chauvinist, imposes severe punishment for every major and minor mistake of Bela:

Due to the stress, Nimi develops pustules on her face, which prompts Jemubhai to further denigrate her waning beauty. Nimi comes to realise the bleakness of her existence. (Bhadoria, 2018, p. 397)

Charming Bela loses her beauty, confidence and presence. The judge warns her not to step out of the house without his permission. Nimiis brought up in such a manner that she accepts the authority of her spouse without any question or apprehension. She is forced to continue her loveless marriage in the suffocating four walls of the house:

She peered out at the world but could not focus on it, never went to the mirror, because she couldn't see herself in it. (Desai, Inheritance, 2006, p. 173)

Nimi suffers identity crisis and turns out to be completely desolate.

The miseries of Nimi and the wrath of the judge keep on increasing. The husband starts beating her and Nimi accepts it as her fate like many other Indian wives: 
Through the story of Nimi, Desai draws a realistic picture of how many women in the Third World suffer. (Lone, 2008, p. 51)

The judge sends her to her parental house when he becomes completely annoyed with her. Bela gives birth to a daughter after six months of her arrival at her parental house. After the death of her father, it is her uncle who is the head of the family now. The uncle telegrams the judge, "Your wife is ready to return" (Desai, Inheritance, 2006, p. 306). Through the reply of the judge, Desai clearly states that there is no place for Nimi and her daughter in his life:

Jemu sent money with a letter. "It will not be suitable," he replied. "My work is such. No schools. Constant travel..." (p. 306)

The agitated uncle shuts the doors of his house on his niece on the pretext that her share has already been given to her in the form of dowry. Bela goes to her sister's house where she is humiliated by her sister's husband:

She had lived the rest of her life with a sister who had not married as successfully, as high up, as Nimi. Her brother-in-law resented every bite that entered Nimi's mouth. (p. 306)

Nimi's callous brother-in-law puts an end to her life. She is burned alive and the judge also wears a blindfold like the Lady Justice:

In the life of Nimi deprivation, injustice, oppression, alienation and isolation are well discernible. It can be stated that she is completely tied with above...Nimi is example which shows how the traditional women are bound to suffer bitter treatment in the name of husband. (Pandey, 2015, p. 4)

Nimi dies as abruptly as she lives in the novel.

\section{Conclusion:}

Both Roy and Desai show considerable similarities while dealing with the theme of identity crisis, but at the same time, there are notable differences given in the portrayal of internal and external struggle in the lives of their women characters. A critical analysis of the novels of Roy and Desai reveal the different dimensions of womanhood in general and wifehood in particular. Roy portrays proactive wives in the form of Ammu, Rahel and Tilo who stress on their individuality by seeking separation from their husbands. Ammu is quite rebellious and Rahel has a tendency to break social taboos. Tilo, on the other hand, is least bothered when she violates social and sexual taboos imposed by the patriarchal society. The trio readily tolerates the family and societal pressures. Ammu divorces Baba and starts a secretive love affair with Velutha. Rahel follows her mother's footsteps by divorcing her husband, Larry McCaslin, and seeks solace in an incestuous relationship with her brother, Estha. Tilogets separated from her husband, Naga, to lead an independent life. Roy is aware of the social and domestic constraints on the Indian wives; still, she valiantly deliberates on multiple options. On the other hand, her counterpart Desai depicts a contrasting view through the subjugation of Bela, alias Nimi Patel. She presents Bela as a passive and idle character with no resistance. The judge, Bela's husband, insults, abuses, beats and finally banishes her from his house and life. To the contrary, Bela is ready to face the torture at the hands of her husband, but seeking separation is out of the question for her. She suffers and dies as the wife of the judge but never tries to explore other alternatives as the wives presented by Roy do. Roy and Desai show an in-depth understanding of womanhood and the predicament of wives in India. They differ while picturing the role of wives and convincingly justify their standpoints. 
Both Roy and Desai present the incessant struggle and inner psyche of their women characters in quest of identity.

\section{References}

Al-Quaderi, GolamGaus, and Muhammad Saiful Islam. (2011). Complicity and Resistance: Women in Arundhati Roy's The God of Small Things.Journal of Postcolonial Cultures and Societies,2(4), 62-78. https://www.researchgate.net/publication/316248661

Bhadoria, Priyanka. (2018). Feminine Quest in Kiran Desai's-The Inheritance of Loss.Research Journal of English Language and Literature 6(1), 396-398. http://www.rjelal.com/6.1.18/396398\%20PRIYANKA\%20BHADORIA.pdf

Desai, Kiran. (1998). Hullabaloo in the Guava Orchard.Faber and Faber Ltd.

Desai, Kiran. (2006). The Inheritance of Loss. Penguin Random House India.

Erikson, Erik H. (1950). Childhood and Society. W. W. Norton Company.

Erikson, Erik H.(1968). Identity: Youth and Crisis. W. W. Norton Company.

Gaikwad, Rupali M. (2017). The Abyss of Culture and Self-Identity: A Study of Indian Women Novelist's Women Characters. In MadhaviNikam, and SudhirNikam (Eds.), Contemporary Discourse: A Peer Reviewed International Journal. (pp. 176-180).

Hariharansudan, A., and S. Robert Gnanamony. (2017). Feministic Analysis of Arundhati Roy's Postmodern Indian Fiction: The God of Small Things. Global Journal of Business and Social Science Review 5(3), 159-164. https://ideas.repec.org/p/gtr/gatrjs/gjbssr489.html

Lone, Sissel Marie. (2008). Race, Gender and Class in The Inheritance of Loss and Brick Lane: A Comparative Study. The University of Oslo, Oslo.

Neelima, C. (2016). Women's Place in a Patriarchal Society: A Critical Analysis of Arundhati Roy's The God of Small Things. European Journal of English Language and Literature Studies 4(1), 37-41. http://www.eajournals.org/wp-content/uploads/Women---s-Place-in-a-Patriarchal-Society-ACritical-Analysis-of-Arundhati-Roy---s-The-God-of-Small-Things.pdf

Pandey, Vipin Kumar. (2015). Feminine Quest in Kiran Desai's The Inheritance of Loss. Pune Research An International Journal in English 1(3), 1-8. http://puneresearch.com/media/data/issues/563b277472755.pdf

Roy, Arundhati. (1997).The God of Small Things. Penguin Random House India.

Roy, Arundhati. (2017). The Ministry of Utmost Happiness. Penguin Random House India.

Rajneesh Kumar is a Ph.D. research scholar pursuing his doctorate from DAV University, Punjab. Currently, he is working as a Sr. Asst. Professor and Head of English Deptt. at Govt. Arts \& Sports College, Jalandhar, Punjab. He is a well-known educationist with a long teaching experience of twenty-one years to his credit. Additionally, he has authored two and edited one book. He has published nine research papers in the journals of repute, including Scopus indexed and UGC CARE listed journals. Chairing two sessions in the international conferences is another feather in his cap. He has presented fourteen papers in international and national level conferences. He has delivered a considerable number of extension lectures in various universities, colleges and schools. He is a recipient of the 'Best Teacher Award' bestowed on him by CT Group of Institutions, Punjab in 2016. 